DOI: https://doi.org/10.47405/mjssh.v5i4.384

\begin{tabular}{|c|c|}
\hline 4 & Malaysian Journal of Social Sciences and Humanities (MJSSH) \\
\hline $\begin{array}{l}\text { Malaysian Journal of } \\
\text { Social sciences and }\end{array}$ & Volume 5, Issue 4, April 2020 \\
\hline (MJ-SSH) & e-ISSN : 2504-8562 \\
\hline & $\begin{array}{l}\text { Journal home page: } \\
\text { www.msocialsciences.com }\end{array}$ \\
\hline
\end{tabular}

\title{
Keputusan Kerusi Parlimen Negeri Sabah Pilihan Raya Umum Ke-14 2018: Satu Analisis
}

\author{
Mohd. Noor Yazid1 \\ 1Program Hubungan Antarabangsa, Fakulti Sains Sosial dan Kemanusiaan, Universiti Malaysia Sabah (UMS) \\ Correspondence: Mohd. Noor Yazid (mohdnoor@ums.edu.my)
}

\begin{abstract}
Abstrak
Artikel ini membincangkan keputusan kerusi parlimen negeri Sabah dalam PRU 14, yang diadakan pada 9 Mei 2018. Kenapa terdapat perbezaan yang besar dalam keputusan pilihanraya umum ke-14 ini berbanding dengan keputusan pilihanraya umum sebelum ini. Keputusan PRU ke-14 di peringkat parlimen Sabah adalah berbeza dengan apa yang berlaku dalam pilihanraya sebelumnya; iaitu penguasaan BN yang merosot di peringkat parlimen Sabah. Perubahan besar telah berlaku dalam PRU ke-14, 9 Mei 2018 di mana parti-parti politik komponen BN telah mengalami kemerosotan besar dalam parlimen Sabah. Daripada jumlah keseluruhan 25 kerusi parlimen seluruh negeri Sabah, BN hanya berjaya mendapat sepuluh kerusi parlimen sahaja. Selebihnya adalah dimenangi oleh parti-parti politik yang bekerjasama dengan Pakatan Harapan iaitu Parti Warisan Sabah (8 kerusi), PKR (3 kerusi) dan DAP (3 kerusi). Ini adalah pertama kali BN mengalami kekalahan teruk dalam pilihanraya umum Sabah. Kajian ini mendapati bahawa isu-isu berkaitan dengan masalah ekonomi negara, dasar ekonomi dan percukaian yang menekan rakyat, kenaikan harga barang serta kenaikan kos hidup, rasuah dikalangan pimpinan tertinggi $\mathrm{BN}$, harga petrol yang mahal telah membawa kepada perubahan besar sokongan pengundi Sabah menolak BN. Semua persoalan ini disokong oleh perubahan dan kecanggihan teknologi komunikasi yang memudahkan berlakunya penyebaran secara meluas kepada seluruh peringkat pengundi. Oleh itu dapat dikatakan bahawa tekonologi komunikasi moden ini mempunyai pengaruh besar kepada keputusan pengundi Sabah.
\end{abstract}

Kata kunci: kerusi parlimen, pilihan raya umum, Pakatan Harapan, Barisan Nasional, Parti Warisan Sabah

\section{The Result of the Sabah Parliamentary Seat in the 14 General Election, 2018: An Analysis}

\begin{abstract}
This article discusses the result of the Sabah parliamentary seat in the 14 General Election that was held on $9^{\text {th }}$ May 2018. Why the result of GE 14 is totally different with the previous general election? The parliamentary result of the Sabah GE-14 is totally different with the previous General Election. BN performed badly in GE 14. BN only won 10 parliamentary seats out of 25 parliamentary seats in Sabah. The rest was won by Parti Warisan Sabah ( 8 seats), PKR (3 seats) and DAP (3 seats). This is the first time of the BN worse performent in the Sabah general election. This study concludes that the issues related to national economic policies, taxation policies, high price index, high cost of living, corruption of the top political leaders and high petrol price strongly influenced the Sabah voters in rejecting the BN candidates. The voters were accessible to the above issues via the modern and sophisticated
\end{abstract}


communication technology. Thus, modern and sophisticated communication plays an important role in influencing the Sabah parliamentary seats result.

Keywords: parliamentary seat, general election, Pakatan Harapan, Barisan Nasional, Parti Warisan Sabah

\section{Pengenalan}

Artikel ini membincangkan keputusan kerusi parlimen dalam PRU 14, 2018. Kenapa terdapat perbezaan dalam keputusan dan pencapaian dan kedudukan parti-parti politik dalam pilihanraya umum (PRU) ke-14, Mei 2018. Barisan Nasional (BN) telah mengalami kekalahan teruk dalam parlimen negeri Sabah dalam PRU ke-14. Peranan dan sumbangan besar yang dimainkan oleh BN Sabah kepada BN pusat yang disumbangkan sebelum ini telah berakhir. Kedudukan dan bilangan anggota BN Sabah sebelum PRU ke-14 kepada pembentukan kerajaan BN adalah sangat penting. Sabah adalah antara tiga buah negeri, bersama-sama dengan negeri Johor dan Sarawak yang memberikan sumbangan besar kepada BN yang membolehkan BN membentuk kerajaan di peringkat pusat.

Bagi memudahkan perbincangan, artikel ini dibahagikan kepada tiga bahagian utama iaitu; bahagan pertama, pencapian BN dan parti-parti politik lain dalam PRU ke-14, 2018 dan; bahagian kedua, kedudukan dan pencapaian parti-parti politik di bawah Pakatan Harapan; bahagian ketiga, adalah perbincangan dan kesimpulan yang difokuskan kepada kenapa terdapat perbezaan besar pencapaian BN dalam PRU ke-14, berbanding dengan apa yang dicapai dalam pilihanraya-pilihanraya sebelumnya.

Perubahan besar telah berlaku dalam keputusan kerusi parlimen PRU ke-14 di negeri Sabah, 2018 berbanding dengan apa yang berlaku dalam pilihanraya-pilihanraya sebelum ini. Parti-parti komponen BN telah mengalami kemerosotan besar. Daripada 25 kerusi parlimen seluruh negeri Sabah, BN hanya berjaya mendapat sepuluh kerusi parlimen sahaja. Selebihnya sebanyak adalah dimenangi oleh partiparti politik yang bekerjasama dengan Pakatan Harapan iaitu Parti Warisan Sabah (8), PKR (3) dan DAP (3). Ini adalah satu perubahan besar kerana dalam PRU ke-13, BN menguasai sebanyak 22 kerusi parlimen di Sabah. Pihak pembangkang pada masa itu (iaitu Pakatan Rakyat) hanya memenangi tiga kerusi sahaja. Ini adalah pertama kali BN mengalami kekalahan teruk dalam pilihanraya umum Sabah. Kekalahan BN yang teruk dalam parlimen negeri Sabah ini memberikan kesan besar terhadap penguasaan BN di peringkat kerajaan pusat. Sekiranya negeri Sabah kekal dengan 22 kerusi parlimen dalam PRU ke-14 (sebagaimana dalam pencapaian dalam pilihanraya umum ke-13), kemungkinan besar BN akan tetap menguasai kerajaan pusat. Ini berasaskan andaian bahawa perubahan serta kemerosotan besar tidak berlaku di Sarawak dan PAS bersetuju bekerjasama dan menyertai BN membentuk kerajaan persekutuan.

Kekalahan BN dalam parlimen negeri Sabah mempunyai hubungan rapat dengan kebencian dan ketidakyakinan sebahagian besar pengundi Sabah terhadap pimpinan BN. Isu-isu berkaitan dengan masalah ekonomi negara, dasar ekonomi dan percukaian yang menekan rakyat, kenaikan harga barang serta kenaikan kos hidup, rasuah dikalangan pimpinan tertinggi BN serta hal-hal yang berkaitan dengan masa depan negara dan kedudukan rakyat biasa yang tidak menentu telah membawa kepada perubahan besar sokongan pengundi Sabah kepada parti-parti politik bukan BN. Penyingkiran Datu Seri Mohd Shafie Apdal daripada menteri kabinet Persekutuan oleh pimpinan Datuk Najib serta pengaruh Shafie dalam politik Sabah, memberikan kesan negatif kepada kedudukan BN/UMNO dalam parlimen dan politik Sabah. Pengaruh Datuk Seri Mohd Shafie Apdal, dan pembentukan Parti Warisan Sabah serta perkembangan pesat teknologi komunikasi mempunyai kesan besar terhadap kemerosotan BN Sabah.

\section{Keputusan dan Pencapian Calon-calon Barisan Nasional dalam PRU ke-14, 2018}

Pencapaian BN di peringkat parlimen negeri Sabah mengalami kemerosotan teruk jika dibandingkan dengan apa yang dicapai dalam dalam keputusan PRU ke-13, Mei 2013. ${ }^{i}$ BN Sabah hanya berjaya 
memenangi 10 kerusi parlimen sahaja, berbanding dengan 22 kerusi parlimen yang dimenangi dalam PRU ke-13, 2013. Tokoh-tokoh besar pimpinan BN/UMNO Sabah mengalami kekalahan di tangan Parti Warisan Sabah, PKR atau DAP. Lima orang anggota kabinet persekutuan, menteri dan timbalan menteri telah mengalami kekalahan. Lima anggota kabinet persekutuan itu ialah Datuk Seri Abdul Rahman Dahlan (Menteri di Jabatan Perdana Menteri), Datuk Seri Dr. Salleh Said Keruak (Menteri Komunikasi dan Multimedia), Datuk Datu Nasun Datu Mansur (Timbalan Menteri Perusahaan Perladangan dan Komoditi), Datuk Mary Yap Kain Ching (Timbalan Menteri Kementerian Pengajian Tinggi) dan Datuk Rosnah Abdul Rashid Shirlin (Timbalan Menteri Kerjaraya) semuanya telah mengalami kekalahan. Kekalahan yang sedemikian tidak pernah berlaku dalam pilihanraya umum sebelum ini. Kebiasaannya kedudukan menteri penuh atau timbalan menteri kabinet di peringkat kerajaan pusat mempunyai hubungan dan pengaruh yang kuat yang menjamin kemenangan seseorang calon. Dalam amalan biasa menteri atau timbalan menteri kabinet persekutuan sukar untuk dikalahkan. Walaupun mungkin berlaku kekalahan, bilangan yang kecil sahaja. Keadaan ini berlaku ada hubungannya dengan falsafah politik pembangunan dimana peranannya cukup besar dalam membangunkan sesebuah kawasan parlimen. Tetapi dalam PRU ke-14 ini para pengundi telah nekad membuat perubahan. Tindakan ini ada hubungan dengan darjah korupsi yang ada di dalam fikiran dan persepsi rakyat, walaupun belum ada keputusan muktamad dan keputusan mahkamah secara sah mengikut lunas undang-undang. Persepsi pengundi ini penting kerana ianya mempengaruhi keputusan di peti undi. ${ }^{\text {ii }}$

Kekalahan calon-calon besar pemimpin $\mathrm{BN}$ ini tdak pernah berlaku sebelum ini. Kekalahan ini ini adalah satu protes terbuka secara demokratik dan rasa tidak puas hati pengundi terhadap calon BN oleh pengundi Sabah. Kebencian dan penolakan ini bukan sahaja disebabkan oleh faktor peribadi calon dan faktor tempatan, tetapi banyak dikaitkan secara langsung dengan faktor kepimpinan dan dasar ekonomi kerajaan pusat pimpinan Datuk Najib. Sesiapa sahaja calon yang menyokong pimpinan Datuk Najib cuba dijatuhkan agar pimpinan Najib dapat ditamatkan dan digantikan dengan pimpinan baru sama ada di peringkat negeri atau pun pusat. Trenda perubahan pengundi yang telah bermula di negeri-negeri Persekutuan Tanah Melayu sejak dua pilihanraya umum lepas telah merebak ke negeri Sabah. Pemecatan Datuk Seri Mohd. Shafie Apdal daripada Kabinet Kerajaan Persekutuan (bersama-sama Tan Sri Muhyiddin Yassin kerana mengkritik pengurusan ekonomi Najib) dan penubuhan Parti Warisan Sabah serta situasi sosio-ekonomi semasa menjelang PRU ke-14 mengukuhkan lagi perubahan sokongan pengundi kepada parti-aparti yang bekerjasama dengan $\mathrm{PH}^{\mathrm{iii}}$

Walaupun tidak semua kerusi parlimen BN berjaya dijatuhkan, tetapi kemenangan calon BN sangat merosot. Daripada 10 kerusi parlimen yang dimenangi oleh BN, beberapa buah kerusi parlimen yang dimenangi oleh calon BN hanya dengan undi majoriti yang sangat kecil. Contohnya seperti apa yang berlaku di kawasan parlimen P. 176 Kimanis dengan hanya dimenangi oleh calon BN hanya dengan 156 undi majoriti. Kemenangan tipis Datuk Seri Anifah Aman di kawasan parlimen P. 176 Kimanis ini satu contoh perubahan besar penolakan pengundi kerana kerusi ini dimenanginya sejak beberapa penggal yang lalu. Dalam PRU ke-13, 2013 pun beliau masih menang dengan majoriti yang agak besar iaitu 5,723 undi majoriti. ${ }^{\text {iv }}$ Undi majoriti seperti ini adalah sangat kecil bagi sebuah kawasan parlimen yang ditandingi oleh seorang anggota menteri kabinet pesekutuan. Dalam PRU sebelum ini, tokohtokoh besar yang memegang jawatan menteri di peringkat pusat biasanya akan menang dengan mudah dan mendapat majoriti yang besar dan sukar untuk dikalahkan. Perubahan besar telah berlaku dalam PRU ke-14 ini kerana kebencian kepada pimpinan UMNO/BN sangat kuat. Hanya 10 kawasan parlimen BN sahaja yang berjaya dipertahankan dalam PRU ke-14. Maklumat mengenai pencapaian 10 kawasan parlimen yang dimenangi $\mathrm{BN}$ adalah seperti yang ditunjukkan dalam jadual 1 di bawah.

Jadual 1: Kawasan Parlimen di Sabah yang dimenangi calon BN dalam PRU ke-14

\begin{tabular}{llcl}
\hline Kawasan Parlimen & $\begin{array}{l}\text { Undi } \\
\text { diperolehi } \\
\text { BN }\end{array}$ & $\begin{array}{c}\text { Undi diperolehi parti } \\
\text { Warisan/PKR/DAP }\end{array}$ & $\begin{array}{l}\text { Majoriti } \\
\text { BN }\end{array}$ \\
\hline P. 167 Kudat & 18,503 & $17,144(w)$ & 1,359 \\
P.168 Kota Marudu & 13,033 & 11,259 (Harapan Rakyat), $7,113(w)$, & 1,774 \\
& \multicolumn{2}{c}{2,501 (Parti Cinta Sabah) } \\
\hline
\end{tabular}


Malaysian Journal of Social Sciences and Humanities (MJSSH), Volume 5, Issue 4, (page 8 - 18), 2020

DOI: https://doi.org/10.47405/mjssh.v5i4.384

\begin{tabular}{lccl}
\hline P`170 Tuaran & 22,494 & $14,870(\mathrm{PKR})$ & 7,624 \\
P.176 Kimanis & 11,942 & $11,786(\mathrm{~W})$ & 156 \\
P.177 Beaufort & 11,354 & 8,023 (Harapan Rakyat), 7,835 (PKR) & 3,331 \\
P.178 Sipitang & 12,038 & $11,186(\mathrm{w})$ & 852 \\
P.182 Pensiangan & 11,783 & $9,469(\mathrm{PKR})$ & 2,314 \\
P.183 Beluran & 13,007 & $5,892(\mathrm{w})$ & 7,115 \\
P.184 Libaran & 17,799 & $17,121(\mathrm{w})$ & 678 \\
P. 187 Kinabatangan & 14,465 & $4,987(\mathrm{w})$ & 9,478 \\
\hline
\end{tabular}

Sumber: Berita Harian, Jumaat 11 Mei 2018, hal. 38-41 (disesuaikan)

Daripada 10 kerusi parlimen yang dimenangi calon $\mathrm{BN}$, hanya empat kerusi sahaja yang dimenangi dengan majoriti yang melebihi 3,000 undi iaitu P. 170 Tuaran, P. 177 Beaufort, P. 183 Beluran dan P. 187 Kinabatangan. Enam kerusi parlimen yang lain hanya dimenangi dengan majoriti kecil di bawah daripada 3,000 majoriti. Kerusi parlimen yang kurang daripada 3,000 undi majoriti itu ialah P. 167 Kudat (1,359 undi), P. 168 Kota Marudu (1,774 undi), P. 176 Kimanis (156 undi), P. 178 Sipitang (852 undi), P. 182 Pensiangan (2,314 undi) dan P.184 Libaran 678 undi). Kemungkinan kerusi-kerusi parlimen ini akan dikuasai oleh Parti Warisan dan parti yang bekerjasama dengannya adalah besar (berdasarkan pengalaman yang belaku dalam PRU-14). Tiga daripada kerusi parlimen yang dimenangi $\mathrm{BN}$ itu adalah dimenangi BN dengan undi majoriti yang kurang daripada 1,000 undi. Undi majoriti yang dimenangi oleh calon BN di kawasan parlimen P. 176 Kimanis adalah paling kecil iaitu hanya 156 undi majoriti. Jumlah ini adalah terlalu kecil bagi seorang yang bertaraf menteri penuh kerajaan pusat.

Pada umumnya pencapaian BN di peringkat parlimen adalah sangat merosot. Secara mudah dapat kita katakan bahawa para pengundi telah menolak BN. Dasar-dasar BN yang menekan rakyat dalam aspek ekonomi khususnya telah banyak mempengaruhi keputusan pengundi terhadap BN. Dasar BN itu lebih difokuskan kepada dasar-dasar ekonomi seperti kenaikan harga barang-barang pengguna, isu rasuah berkaitan dengan $1 \mathrm{MDB}$, isu GST telah banyak mempengaruhi keputusan pengundi Sabah. Persoalan di sini (yang ditafsirkan oleh majoriti pengundi) adalah sama ada benar atau tidak tentang apa yang didakwa oleh pihak Parti Warisan dan parti-parti yang menyokong Pakatan Harapan; apa yang penting adalah kesan yang dihadapi oleh rakyat. Persoalan yang ditimbulkan oleh rakyat adalah kenapa harga barang meningkat di bawah pimpinan Datuk Najib; kenapa GST mesti diperkenalkan (sejak sekian lama dari mencapai kemerdekaan) negara Malaysia boleh hidup maju dan baik tanpa GST.

Pendirian kerajaan BN/UMNO yang tidak berganjak daripada mempertahankan perlaksanaan GST menjelang pilihanraya telah menimbulkan ketidakyakinan rakyat terhadap pimpinan Datuk Najib. Rakyat terfikir apakah nasib mereka dalam tempoh masa lima tahun selepas Mei 2018 jika BN terus berkuasa melalui PRU ke-14. Dalam fikiran kepala mereka akan berlaku sebuah kehidupan yang sukar dan mungkin akan lebih sukar daripada apa yang dihadapi sekarang (sebelum PRU 9 Mei 2018). Sebagai jalan penyelesaian kerajaan pimpinan Datuk Najib mesti dijatuhkan dan ingin mencuba dengan kerajaan baru pimpinan Parti Warisan dan parti-parti DAP dan PKR yang bekerjasama dengan Pakatan Harapan. Manifesto pilihanraya dan janji-janji Pakatan Harapan telah berjaya menarik sokongan pengundi. ${ }^{\text {vi }}$ Dengan faktor ketidakyakinan para pegundi terhadap BN/UMNO berlaku perubahan besar dalam keputusan parlimen negeri Sabah.

\section{Kedudukan dan Pencapaian Calon-calon Pakatan Harapan: Parti Warisan Sabah, PKR dan DAP di peringkat Parlimen di negeri Sabah dalam PRU ke-14}

Parti Warisan Sabah, DAP dan PKR menguasai 14 kerusi parlimen melalui PRU ke-14, satu peningkatan yang besar berbanding dengan apa yang dicapai dalam pilihanraya sebelumnya. Jumlah ini lebih besar daripada yang dikuasai BN iaitu 10 buah kerusi parlimen. 8 kerusi dimenangi oleh Parti Warisan Sabah dan masing-masing tiga oleh PKR dan DAP. Ini adalah pencapaian yang besar berbanding dengan apa yang dicapai dalam PRU ke-13, tahun 2013. Dalam PRU-13, PKR hanya berjaya memenangi satu kerusi dan DAP dua buah kerusi parlimen. Kesemua jumlah kerusi parlimen dari negeri Sabah yang dimenangi oleh Pakatan Rakyat hanyalah 3 kerusi parlimen sahaja. ${ }^{\text {vii }}$ PKR 
menang di P.174 Penampang dan DAP menang di P.172 Kota Kinabalu dan P. 186 Sandakan dalam pilihanraya umum 2013. ${ }^{\text {viii }}$

\section{Keputusan dan kedudukan Parti Warisan Sabah}

Parti Warisan Sabah adalah sebuah parti politik yang baru dibentuk. PRU ke-14 ini adalah kali pertama bertanding dalam pilihanraya umum. Ianya mendapat kejayaan besar, iaitu berjaya menang di 8 buah kerusi parlimen. Kawasan parlimen yang dimenangi Parti Warisan Sabah adalah P. 169 Kota Belud, P. 171 Sepanggar, P. 174 Penampang, P.175 Papar, P.185 Batu Sapi, P. 188 Silam, P. 189 Semporna dan P. 191 Kalabakan (seperti yang ditunjukkan dalam jadual 2 di bawah). Kerusi-kerusi yang dimenangi oleh Parti Warisan dalam PRU-14 ini adalah boleh dianggap "kerusi-kerusi selamat" BN iaitu kerusikerusi yang dimenangi oleh anggota BN dengan majoriti besar dalam PRU-13, 2013. ${ }^{\text {ix }}$ Jumlah kerusi majoriti besar ini sukar ditembusi oleh calon Warisan berasaskan aliran biasa dan pola pengundian sebelum ini. Perubahan besar telah berlaku di kalangan pengundi Sabah di mana pemimpin besar BN negeri Sabah telah Berjaya dikalahkan. Dua orang menteri kerajaan pusat dan tiga orang timbalan menteri kabinet pusat berjaya dikalahkan oleh calon Parti Warisan Sabah.

Parti Warisan Sabah mengalami kekalahan di lapan buah kerusi parlimen yang ditandinginya iaitu P. 167 Kudat, P. 168 Kota Marudu, P. 176 Kimanis, P. 178 Sipitang, P. 180 Keningau, P. 183 Beluran, P. 184 Libaran dan P. 187 Kinabatangan. Walaupun mengalami kekalahan di lapan buah kerusi parlimen, tetapi Parti Warisan Sabah ini mempunyai sokongan yang kuat berdasarkan jumlah undi yang diperolehi. Ianya mempunyai potensi untuk memenangi lebih banyak kerusi pada masa depan sekiranya pola pengundian tidak berubah. Beberapa kerusi parlimen Parti Warisan hanya kalah dengan majoriti yang kecil sahaja. Ini berlaku di P. 176 Kimanis, P. 178 Sipitang, P. 180 Keningau dan P. 184 Libaran. Calon Parti Warisan di P.180 Keningau, iaitu Jikulin Nointin@Anastasius hanya kalah dengan perbezaan 45 undi. Beliau mendapat sebanyak 13,241 undi, manakalan calon solidariti iaitu Jeffrey Kitingan (yang memenangi kerusi parlimen ini) mendapat 13, 286 undi. Calon BN di P. 180 Keningau, Daniel Kinsik mendapat 12,742 undi. Persaingan sengit tiga penjuru berlaku antara BN, Parti Warisan dan Solidariti di kawasan parlimen Keningau. ${ }^{\mathrm{x}}$

Calon Warisan di P. 176 Kimanis, iaitu Karim Bujang mendapat 11,786 berbanding dengan calon BN mendapat 11,942 undi. Majoriti kecil diperolehi BN di parlimen Kimanis dengan hanya perbezaan 156 undi sahaja. ${ }^{\text {xi }}$ Calon Warisan di P. 184 Libaran juga mendapat sokongan yang besar. IrwanShah Mustapa mendapat 17,121 undi berbanding dengan calon BN, Datuk Zakaria Mohd Edris @ Tubau mendapat 17, 799 undi. Calon Parti Warisan di P. 180 Keningau hanya kalah dengan perbezaan 45 undi, calon Warisan di P. 176 Kimanis dengan hanya perbezaan 156 undi sahaja dan di P. 184 Libaran dengan 678 undi.

Jadual 2: Kerusi Parlimen Sabah yang dimenangi calon Parti Warisan Sabah, PRU-14

\begin{tabular}{lccc}
\hline Kawasan Parlimen & $\begin{array}{c}\text { Jumlah undi } \\
\text { diperolehi parti } \\
\text { Warisan }\end{array}$ & $\begin{array}{c}\text { Jumlah Undi yang } \\
\text { diperolehi BN }\end{array}$ & $\begin{array}{c}\text { Majoriti undi Parti } \\
\text { Warisan }\end{array}$ \\
\hline P.169 Kota Belud & 23,429 & 19,167 & 4,262 \\
P.171 Sepanggar & 28,420 & 15,436 & 12,984 \\
P.174 Penampang & 32,470 & 8,997 & 23,473 \\
P.175 Papar & 17,315 & 17,130 & 185 \\
P.185 Batu Sapi & 12,976 & 8,357 & 4,619 \\
P.188 Silam & $23,, 532$ & 16,951 & 6,401 \\
P.189 Semporna & 26809 & 6,135 & 20,674 \\
P.191 Kalabakan & 18,486 & 15,299 & 3,187 \\
\hline Sun
\end{tabular}

Sumber: Berita Harian, Jumaat 11 Mei 2018, hal. 39-41. 


\section{Kedudukan dan Pencapaian Calon-calon PKR}

PKR bertanding di enam kawasan parlimen dalam PRU ke-14 di Sabah. Daripada jumlah itu PKR berjaya memenangi sebanyak tiga buah kerusi parlimen. Kerusi parlimen yang dimenangi PKR adalah P.173 Putatan, P.179 Ranau dan P.190 Tawau. Calon PKR di kawasan parlimen P. 190 Tawau, Christina Liew Chin Jin berjaya mengalahkan calon BN Datuk Mary Yap Kain Ching (timbalan menteri Kementerian Pendidikan Tinggi) yang telah bertapak di situ selama dua penggal dengan majoriti 4,979 undi dalam pilihanraya umum ke-13, 2013. ${ }^{\text {xi }}$ Secara tradisinya kawasan parlimen Tawau dikuasai oleh calon BN. Dalam pilihanraya umum ke-12, 2008 calon BN di kawasan parlimen P. 190 Tawau, Chua Soon Bui menang dengan majoriti 4,867 undi mengalahkan calon DAP dan calon PKR. Ketidak-sepakatan antara parti politik Pakatan Rakyat di Sabah dalam pilihanraya 2008 adalah salah satu sebab yang membawa kepada kemenangan calon BN. ${ }^{\text {iii }}$ Kalau berlaku kerjasama antara PKR dan DAP di kawasan parlimen Tawau, cabaran terhadap BN akan lebih besar. Dalam pilihanraya umum 2004, calon BN parlimen Tawau iaitu Shim Pau Fatt menang tanpa bertanding. ${ }^{\text {xiv }}$ Tiga buah kerusi lagi yang gagal dimenangi calon PKR juga mendapat sokongan dan jumlah undi popular yang agak besar, walau gagal untuk menawan kerusi-kerusi tersebut. Potensi untuk menang dalam pilihanraya akan datang adalah cerah sekiranya tidak berlaku pola perubahan politik di peringkat nasional. Maklumat lanjut sila lihat jadual 3 di bawah.

Jadual 3: Keputusan calon-calon Parlimen PKR Sabah, PRU 14

\begin{tabular}{lccc}
\hline Kawasan Parlimen & $\begin{array}{c}\text { Jumlah Undi } \\
\text { diperolehi PKR }\end{array}$ & $\begin{array}{c}\text { Jumlah Undi } \\
\text { diperolehi BN }\end{array}$ & $\begin{array}{c}\text { Undi Majoriti (P. 173, } \\
\text { P. 179 \& P. 190 } \\
\text { dimenangi PKR) }\end{array}$ \\
\hline P.170 Tuaran & 14,870 & 22,494 & 7,624 \\
P.173 Putatan & 14,106 & 11,767 & 2,339 \\
P.177 Beaufort & 11,354 & 7,835 & 3,331 \\
P.179 Ranau & 14,880 & 13,804 & 1,076 \\
P.182 Pensiangan & 9,469 & 11,783 & 2,314 \\
P.190 Tawau & 21,400 & 16,673 & 4,727 \\
\hline
\end{tabular}

Sumber: Berita Harian, Jumaat 11 Mei 2018, hal. 38-41

\section{Kedudukan dan Pencapaian calon-calon DAP}

DAP bertanding di tiga kawasan parlimen dalam PRU ke-14 Sabah, iaitu di P.172 Kota Kinabalu, P. 186 Sandakan dan P. 181 Tenom. DAP berjaya memenangi semua kerusi yang ditandinginya. DAP mendapat majoriti besar di P. 172 Kota Kinabalu dan P. 186 Sandakan. Kedua-dua kawasan parlimen ini adalah kawasan majoriti pengundi kaum Cina. Kota Kinabalu terdiri daripada $70.1 \%$ pengundi kaum Cina dan parlimen Sandakan pula $51.6 \%$.

Calon DAP di P. 186 Sandakan, Stephen Wong Tien Fatt berjaya mengalahkan calon BN, Lim Ming Ho dengan majoriti sebanyak 10,098 undi. Walaupun pengundi kaum Cina hanya sebanyak $51.6 \%$ daripada keseluruhan pengundi, tetapi manifesto $\mathrm{PH}$ dan perkembangan politik semasa telah berjaya menarik sokongan kepada calon DAP daripada semua kaum berasaskan semangat kerjasama Pakatan $\operatorname{Harapan}^{\mathrm{xv}}$.

Calon DAP di parlimen Kota Kinabalu, iaitu Chan Foong Hin menang dengan majoriti besar 24,086 undi mengalahkan dua calon lain daripada BN dan SAPP. Calon DAP mendapat 31,642 undi jauh lebih besar sokongan terhadap calon BN Lee Hyan Kyun 7,546 dan calon SAPP Yong Teck Lee hanya mendapat 3,132 undi. ${ }^{\text {xvi }}$ Parlimen Kota Kinabalu boleh dianggap sebagi kubu kuat DAP yang dikuasai DAP sejak beberapa pilihanraya lalu. ${ }^{\text {xvii }}$

Calon DAP di P. 181 Tenom iaitu Noorita Sual menang dengan majoriti 1,133 undi. Berlaku pertanding tiga penjuru di P. 181 Tenom iaitu calon DAP, calon BN Rubin Balang dan calon Parti Harapan Rakyat, Laimoi @ Yuslinah Laikim. Pertandingan sebenar adalah antara DAP dan BN. Calon 
Parti Harapan Rakyat hanya mendapat sokongan yang sangat kecil iaitu 645 undi sahaja. Data-data terperinci pencapaian calon-calon DAP sila lihat jadual 4 di bawah.

Jadual 4: Keputusan calon-calon Parlimen DAP Sabah, PRU 14

\begin{tabular}{|c|c|c|c|c|}
\hline Kawasan Parlimen & $\begin{array}{l}\text { Jumlah } \\
\text { diperolehi } \\
\text { DAP }\end{array}$ & $\begin{array}{l}\text { Undi } \\
\text { calon }\end{array}$ & $\begin{array}{l}\text { Jumlah Undi } \\
\text { BN/calon-calon liperolehi } \\
\text { bertanding }\end{array}$ & $\begin{array}{l}\text { Undi } \\
\text { Majoriti }\end{array}$ \\
\hline P.172 Kota Kinabalu & 31,632 & & $\mathrm{BN}=7,546, \mathrm{SAPP}=3,132$ & 24,086 \\
\hline P.181 Tenom & 11,363 & & $\begin{array}{l}\mathrm{BN}=10,230, \\
\text { Harapan Rakyat }=645\end{array}$ & 1,133 \\
\hline P. 186 Sandakan & 19,094 & & $\mathrm{BN}=8996$ & 10,098 \\
\hline
\end{tabular}

Sumber: Berita Harian, Jumaat 11 Mei 2018 (disesuaikan)

\section{Perbincangan dan Kesimpulan}

Kenapa terdapat perbezaan besar antara pencapaian BN dalam PRU ke-14, berbanding dengan apa yang dicapai dalam pilihanraya-pilihanraya sebelumnya? Berdasarkan apa yang telah dibincangkan di atas, kajian ini menyimpulkan bahawa dasar-dasar ekonomi kerajaan pusat pimpinan Datuk Seri Najib seperti isu $1 \mathrm{MDB}$, isu GST, kos hidup yang tinggi serta harga barangan yang sentiasa meningkat dan tekanan ekonomi yang mengcengkam rakyat mempunyai hubungan yang rapat dengan trenda pengundian dan keputusan dalam PRU ke-14 di negeri Sabah. Faktor kepimpinan Datuk Seri Mohd. Shafie Apdal serta beberapa faktor tempatan juga turut menyumbang kepada kekalahan BN dan kemenangan besar Parti Warisan Sabah dan parti-parti komponen PH yang bekerjasama dengannya. Walaupun isu nasional itu penting, tetapi isu tempatan peringkat negeri seperti hal-hal berkaitan dengan Perjanjian Malaysia 1963 tetap mempunyai pengaruh dalam keputusan PRU ke-14 di Sabah. ${ }^{\text {xiii }}$ Apa yang diputuskan oleh pengundi di Sabah adalah mempunyai arah aliran dan pola yang hampir sama dengan keputusan dan pola pengundian yang berlaku di negeri-negeri lain di Persekutuan Tanah Melayu dan juga keputusan pengundi negeri Sarawak. Polisi kerajaan pusat di bawah pimpinan Perdana Menteri Datuk Seri Najib Tun Razak mempengaruhi keputusan sebahagian besar pengundi Sabah. Sekiranya tidak ada polisi-polisi dan keputusan ekonomi Najib yang menekan kehidupan rakyat, besar kemungkinan keputusan PRU ke-14 berbeza. Sekiranya Datuk Najib berjanji dan meyakinkan rakyat akan mengubah beberapa dasar seperti penurunan kadar GST, menurunkan harga minyak petrol mungkin keputusan PRU ke-14 akan turut berbeza. Apa yang berlaku adalah pimpinan utama $\mathrm{BN}$ dan juga pimpinan $\mathrm{BN}$ peringkat negeri serta bawahan tidak benar-benar memahami masalah yang dihadapi rakyat umum. Masalah utama rakyat tidak cuba disentuh serta disesuaikan semasa kempen pilihanraya dan tidak berlaku "dialog terbuka dari hati ke hati"dalam kempen-kempen pilihanraya. ${ }^{\text {xix }}$ Pimpinan BN dan pekerja-pekerja parti masih memegang prinsip "cash is king" iaitu para pengundi negeri Sabah masih boleh ditarik sokongan mereka kepada BN dengan sogokan wang di saat akhir menjelang hari mengundi. Mereka masih percaya bahawa kuasa wang boleh menarik sokongan pengundi kepada pihak BN/UMNO. Dalam situasi tekanan ekonomi yang buruk dan tahap kemarahan rakyat umum kepada pimpinan BN yang meluap-luap, kuasa wang telah tidak berjaya lagi mempengaruhi keputusan sebahagian besar pengundi. Peranan teknologi komunikasi yang canggih, cepat dan meluas mampu menyebar dan memaparkan realiti isu-isu utama dan korupsi pemimpin utama BN kepada seluruh pengundi. Ini adalah satu perkembangan baru yang mempunyai pengaruh besar yang tidak berlaku dengan meluas dalam pilihanraya-pilihanraya sebelum ini. ${ }^{\mathrm{xx}}$

Apa yang dilakukan oleh pengundi Sabah dalam PRU ke-14 adalah berbeza dengan apa yang telah dilakukan dalam PRU ke-12, 2008 dan PRU ke-13, 2013. Dalam dua pilihanraya tahun 2008 dan 2013 sebelum ini ledakan penggunaan teknologi komunikasi belum benar-benar meluas sebagaimana dalam pilihanraya 2018. Tokoh dan kepimpinan menentang BN seperti Datuk Mohd. Shafie Apdal tidak wujud dalam pilihan raya sebelum ini. Sebahagian besar rakyat sudah tidak yakin dengan manifesto pilihanraya dan janji-janji $\mathrm{BN}$, bahkan rakyat merasa takut bagi menghadapi tempoh masa lima tahun akan datang jika BN terus menang dan berkuasa sebagai pemerintah. Dalam PRU ke-12 dan PRU ke13 pola pengundian di Sabah adalah berbeza dengan apa yang berlaku di Persekutuan Tanah Melayu, 
iaitu sokongan tetap diberikan kepada BN ketika sebahagian besar pengundi di negeri-negeri Persekutuan Tanah Melayu telah memberikan sokongan kepada Pakatan Rakyat. ${ }^{x i}$ Dalam PRU ke12, BN Sabah masih menguasai 24 kerusi parlimen, iaitu salah sebuah negeri yang memberi sumbangan besar bagi menjamin kerajaan pusat terus dikuasai BN. Tiga buah negeri yang memberi sumbangan besar kepada BN terus mengusai kerajaan pusat adalah Johor, Sabah dan Sarawak. Negerinegeri lain telah menunjukkan sokongan yang kecil terhadap BN dan telah memberikan sokongan besar kepada PR. Jika tiga buah negeri ini tidak memberikan sokongan besar kepada BN, besar kemungkinan PRU 2008 telah mengubah kerajaan pusat Malaysia kepada Pakatan Rakyat. ${ }^{\text {xxii }}$

Hanya sebuah kerusi parlimen, iaitu P. 172 Kota Kinabalu yang dimenangi oleh DAP dalam PRU ke12. Semua kerusi parlimen lain masih dimenangi oleh BN dengan majoriti selamat. ${ }^{\text {xxii }}$ Kedudukan anggota parlimen BN di Sabah sedikit tergugat dalam PRU ke-13, dimana tiga buah kerusi parlimen telah jatuh ke tangan pihak Pakatan Rakyat. P. 172 Kota Kinabalu dan P. 186 Sandakan (dua kawasan majoriti pengundi kaum Cina) dimenangi oleh DAP, manakala P. 174 Penampang (32 peratus pengundi Cina) dimenangi oleh PKR. PRU ke-13 telah menampakkan beberapa perubahan yang calon BN telah mula di tolak oleh pengundi Sabah. ${ }^{\text {xxiv }}$ Beberapa kawasan parlimen seperti P. 168 Kota Marudu dan P. 177 Beaufort, calon BN hanya menang dengan mendapat undi majoriti yang lebih kecil daripada PRU-12.

Selepas PRU ke-14 Sabah tidak lagi dianggap sebagai simpanan tetap BN yang menjadi sumbangan besar kepada kekuatan BN/UMNO. BN hanya menguasai 10 kerusi parlimen (daripada 25 kerusi). Beberapa kerusi parlimen yang dimenangi $\mathrm{BN}$ juga hanya dengan majoriti yang sangat kecil. Kerusi parlimen P. 176 Kimanis dimenangi BN dengan majoriti yang sangat kecil iaitu kurang 200 undi, ${ }^{\text {xx }}$ manakala kerusi parlimen P. 178 Sipitang dan P. 184 Libaran dengan majoriti kurang daripada 900 undi. Kuasa politik baru pimpinan Datuk Seri Mohd. Shafie Apdal telah mendapat sokongan majoriti dan berjaya mengusai politik dan pentadbiran Sabah. Negeri Sabah sudah tidak lagi menjadi negeri simpanan tetap bagi BN seperti sebelum PRU ke-14. ${ }^{\text {xxvi }}$ Jumlah kerusi parlimen yang dimenangi BN di Sabah tidak lagi mampu memberi sumbangan besar kepada pembentukan kerajaan pusat seperti yang berlaku dalam pilihanraya-pilihanraya umum sebelum ini.

\title{
Nota:
}

\begin{abstract}
i Dalam pilihanraya-pilihanraya umum sebelum PRU ke-14, anggota parlimen dari Sabah memberi sumbangan yang sangat besar kepada kekuatan BN peringkat pusat. Misalnya dalam PRU ke-12, 2008 ketika kebanyakkan negeri-negeri di Persekutuan Tanah Melayu (kecuali Johor) BN mengalami kekalahan, Sabah kekal dengan sumbangan 24 buah kerusi parlimen. Hanya satu buah kerusi parlimen sahaja BN gagal pertahankan. Oleh itu Sabah dianggap sebagai "simpanan tetap" bagi BN. Perbincangan lanjut tentang penting kedudukan Sabah, sila lihat Mohd. Noor Mat Yazid. (2019). Faktor Sabah, Sarawak dan Johor dalam Pembentukan kerajaan Pusat Malaysia; Analisis Pilihanraya Umum ke-13 dan ke-14, International Journal of Law, Government and Communication, 4 (4), 87-96.
\end{abstract}

ii Ini adalah perkembangan yang agak luar biasa dan jarang berlaku sebelum PRU ke-14, Mei 2018. Sebelum ini calon yang mempunyai kedudukan yang baik di peringkat pusat seperti menteri penuh atau timbalan menteri biasanya akan menang dengan mudah dalam pilihanraya umum.

iii Pemecatan dan pengaruh Datuk Seri Mohd. Shafie Apdal mempunyai pengaruh yang besar kepada perubahan trenda pengundi dan keputusan PRU ke-14 di negeri Sabah.

iv Dalam Pilihanraya umum ke-13, Mei 2013 Datuk Seri Anifah Aman mendapat sebanyak 13,754 undi mengalahkan tiga calon lain iaitu; Jaafar Ismail (PKR) mendapat 8031 undi, Jamil William (SAPP) mendapat 650 undi dan Liusin Malangus (STAR) mendapat 240 undi. Datuk Seri Anifah mendapat undi majoriti sebanyak 5,723 undi, iaitu undi majoriti yang selamat. Walaubagaimana pun perubahan besar sokongan berlaku, iaitu beliau menang dengan majoriti sangat kecil 156 undi sahaja dalam pilihanraya umum ke-14, Mei 2018. Pada Disember 2019 keputusan itu diistiharkan tidak sah oleh mahkamah dan satu pilihanraya kecil diadakan pada 18 Januari 2020. Lihat Berita Harian, Selasa 7 Mei 2013 hal. 35.

v Keputusan pilihanraya umum di P. 176 Kimanis ini diputuskan tidak sah oleh mahkamah pada Disember 2019 dan PRK diadakan pada 18 Januari 2020. PRK ini dimenangi oleh calon BN iaitu Datuk 
Mohammad Alimin dengan majoriti yang lebih besar iaitu lebih 2,000 undi mengalahkan calon Warisan Datuk Karim Bujang. Kemenangan calon BN ini dilihat sebagai undi protes rakyat yang tidak menyukai dasar-dasar kerajaan $\mathrm{PH}$.

vi Perkembangan berlaku selepas setahun lebih pendbiran kerajaan Pakatan Harapan yang tidak memenuhi janji dan manifesto pilihanraya PH telah memberi kesan negatif kepada sokongan pengundi kepada parti-parti politik gabungan Pakatan Harapan. Trenda sokongan pengundi terhadap calon-calon PH telah menurun dalam beberapa PRK seperti parlimen Tanjong Piai, Johor pada 16 November 2019 dan parlimen Kimanis, Sabah pada 18 Januari 2020. Dalam kedua-dua PRK ini calon Parti Warisan Sabah (di parlimen Kimanis) dan calon Parti Bersatu /PBBM dikalahkan oleh calon BN (UMNO di Kimanis dan MCA di Tanjong Piai).

vii Angka-angka terperinci tentang kemenangan PKR di P. 174 Penampang, DAP di P. 172 Kota Kinabalu dan DAP di 186 Sandakan sila lihat Berita Harian, Selasa 7 Mei 2013.

viii Perbincangan lanjut tentang pencapaian DAP dan pola pengundian di kawasan majority kaum Cina di Sabah sila lihat Mohd. Noor Mat Yazid dan Md. Saffie Abd Rahim (2018). Pencapaian Barisan Nasional dan DUN Majoriti Pengundi kaum Cina di Negeri Sabah: Satu Analisis Perbandingan PRU-13 dan PRU14. Jurnal Kinabalu, keluaran Khas 2018.

ix Kerusi-kerusi 'parlimen selamat' ini adalah merujuk kepada kerusi-kerusi parlimen BN yang dimenangi dengan undi majoriti yang besar dalam pilihanraya umum ke-13, Mei 2013. Di antara kerusi parlimen ini adalah P. 169 Kota Belud, P. 171 Sepangar, P. 175 Papar, P. 188 Silam, P. 189 Semporna dan P. 191 Kalabakan. Kerusi-kerusi parlimen yang dianggap selamat (dengan menang majoriti besar dalam PRU ke-13) telah berjaya dimenangi oleh calon Parti Warisan Sabah. Misalnya parlimen P. 175 Papar dimenangi oleh BN dengan majoriti 10,535 undi dalam PRU ke-13; P. 188 Silam dengan majoriti 13,387 undi dan; P. 191 Kalabakan dengan majoriti 14,221 undi. Penjelasan lanjut sila lihat Mohd. Noor Mat Yazid dan Md. Saffie Abd. Rahim. (2019). Berakhirnya Simpanan Tetap Barisan Nasional dan Bermulanya Kuasa Politik Baru di Negeri Sabah. dalam Zulkarnain Abdul Rahman, Rosmadi Fauzi dan Amer Saifude Ghazali (eds.). Pilihan raya Umum ke-14: Isu dan Cabaran Malaysia Baru, Kuala Lumpur; Penerbit Universiti Malaya, 359-376.

x Walaupun terdapat pertandingan 6 penjuru di P. 180 Keningau iaitu calon Parti Cinta Sabah (PCS), 2 orang calon BEBAS, BN, Parti Warisan Sabah dan SOLIDARITI, tetapi persaingan sebenar adalah antara tiga calon iaitu BN, Warisan dan SOLIDARITI sahaja. Calon PCS, Jius Awang hanya mendapat 433 undi, Calon Bebas Maimin Rijan mendapat 248 undi dan; calon Bebas Justin Guka hanya mendapat 199 undi. Persaingan sebenar adalah antara BN, Warisan dan Solodariti seperti yang ditunjukkan dalam jadual di bawah.

Keputusan 3 calon utama PRU 14 di kawasan parlimem P. 180 Keningau, Sabah.

\begin{tabular}{|l|l|}
\hline Parti & Jumlah undi \\
\hline Barisan Nasional ( Daniel Kinsik) & 12,742 \\
\hline Parti Warisan Sabah (Jikulin Nointin@Anastasius) & 13,241 \\
\hline Jeffrey Kitingan (SOLIDARITI) & 13,286 \\
\hline Majoriti (13,286-13,241) & 45 undi \\
\hline
\end{tabular}

Sumber: Keputusan Penuh PRU 14, Berita Harian, Jumaat 11 Mei 2018, hal. 40 (disesuaikan)

xi Calon Parti Warisan di P. 180 Keningau hanya kalah dengan perbezaan 45 undi dan calon Warisan di P. 176 Kimanis dengan hanya perbezaan 156 undi sahaja. Lihat Berita Harian, Jumaat 11 Mei 2018, hal. 39 dan hal. 40.

xii Angka yang terperinci tentang keputusan parlimen P. 190 Tawau, sila lihat Berita Harian, Selasa 7 Mei 2013, hal 37.

xiii Jumlah undi yang di perolehi oleh calon PKR dan DAP jika digabungkan adalah lebih besar daripada undi yang diperolehi oleh calon BN, Chua Soon Bui iaitu 13, 943 undi. Calon DAP Chan Foong Hin mendapat 9,076 undi manakala calon PKR Berhan @ Birhan Ruscan mendapat 3,278 undi. $(9,076+3,278=12,354)$ Jika DAP dan PKR bekerjasama dengan meletakkan satu calon sahaja, maka cabaran calon BN dilihat akan lebih mencabar. Lihat Keputusan Penuh Pilihan Raya Umum 2008, Berita Harian, Isnin 10 Mac 2008, hal. 43. 
xiv Angka yang lebih terperinci sila lihat Berita Harian, Isnin 10 Mac 2008, hal. 43.

xv Penulis berada selama 10 hari di kawasan parlimen Sandakan menjelang Pilihanraya umum ke-14. Daripada pemerhatian dan ikutserta penulis didapati Bilik Gerakan DAP Tanjong Papat (satu daripada kawasan DUN dalam kawasan parlimen Sandakan) mendapat kerjasama rapat daripada semua bangsa dan keturunan, bukan hanya daripada kaum Cina sahaja. Manifesto Pilihanraya DAP/PH telah berjaya menarik sokongan semua kaum, terutamanya golongan muda. Sebagai contoh pembayaran balik PTPTN hanya perlu dibayar balik apabila peminjam telah berjaya bekerja dengan gaji sekurang-kurangnya rm4,000 sebulan. Mendiang Stephen (Wong Tien Fatt, calon parlimen P. 186 Sandakan) dan Frankie (Poon Ming Fong, calon DUN N. 46 Tanjong Papat) sangat mesra rakyat kepada semua kaum, senang dihubungi dan mudah untuk bekerjasama. Faktor ini penting bagi kemenangan DAP dan PH.

xvi Slogan "Sabah for Sabahan" sudah tidak lagi berjaya menarik sokongan pengundi. Persoalan kos hidup, isu-isu ekonomi yang dikaitkan dengan salah guna kuasa dan rasuah yang berlaku diperingkat kuasa kerajaan pusat lebih mendapat perhatian pengundi. Calon yang menggunakan slogan "Sabah for Sabahan" gagal menarik sokongan besar pengundi.

xvii Lihat Mohd. Noor Yazid (2013). DAP, Pakatan dan Politik Malaysia. Jurnal Pemikir, 71 (JanuariMac), 49-66 dan lihat juga Mohd. Noor Mat Yazid dan Md. Saffie Abd Rahim. (2018). Pencapaian Barisan Nasional dan DUN Majoriti Pengundi kaum Cina di Negeri Sabah: Satu Analisis Perbandingan PRU-13 dan PRU-14. Jurnal Kinabalu ( keluaran Khas 2018).

xviii Perbincangan tentang isu tempatan dan berkaitan dengan semangat kenegerian sila lihat Chin, James. (2018). Sabah and Sarawak in the $14^{\text {th }}$ General Election 2018 (GE14): Local Factors and State Nationalism. Journal of Current Southesat Asian Affairs, 37 (3) (Special Issue: The 2018 Malaysian General Elections), hal. 173-192.

xix Pekerja-pekerja parti BN dan UMNO khususnya masih menggunakan kaedah dan pendekatan lama. Sebagai contoh mengadakan persembahan nyanyian dan cabutan bertuah bagi menarik ramai rakyat massa datang ke majlis kempen. Penerokaan sebenar bagi mencari jalan menarik sokongan pengundi tidak berlaku secara menyeluruh kerana pekerja-pekerja masih berpendapat BN/UMNO akan terus menang dan berkuasa membentuk kerajaan seperti dalam pilihanraya sebelum ini. Laungan slogan seperti "Tatap BN" (dalam bahasa tempatan Sabah bermaksud "tetap akan menyokong BN") dilaungkan dalam kebanyakan kempen BN.

xx Lihat Tapsell, R. (2018). The Smartphone as the "Weapon of the Weak": Assessing the Role of Communication Technologies in Malaysia's Regime Change. Journal of Current Southesat Asian Affairs, 37(3), 9-29.

xxi Penjelasan lanjut silat lihat Mohd. Noor Yazid. (2011). Percaturan Kuasa dan Politik Pilihanraya, Kuala Lumpur: Utusan Publications \& Distributors Sdn. Bhd., hal. 176-177, lihat juga Mohd. Noor Yazid. (2010). Merenung Pilihan Raya ke-13: Melayu Gawat, Barisan Tergugat. Jurnal Pemikir, 60 (April-Jun), 81-104.

xxii Lihat Mohd. Noor Mat Yazid. (2019). Faktor Sabah, Sarawak dan Johor dalam Pembentukan Kerajaan Pusat Malaysia: Analisis Pilihanraya Umum ke-13 dan ke-14. International Journal of Law, Government and Communication, 4 (4), 87-96.

xxiii Lihat Danny Wong Tze Ken. (2011). Pilihan Raya Umum ke-12 di Sabah: Beberapa Pemerhatian. dalam Joseph M. Fernando, Zulkarnain Abdul Rahman dan Suffian Mansor (eds), Pilihan Raya Umum Malaysia ke-12: Isu dan pola Pengundian, Kuala Lumpur: Penerbit Universiti Malaya, hal. 249-262.

xxiv Kedudukan Barisan Nasional dan Pakatan Rakyat dalam Pilihanraya umum ke-13, 2013 sila lihat Mohd. Noor Yazid. (2016). Tiang Seri Perlembagaan dan Kuasa Politik Melayu, Kota Bharu: Pustaka Aman Press Sdn. Bhd, hal. 64-72 (Bab 5; Kedudukan Barisan Nasional dan Pakatan Rakyat di Sabah dan Sarawak).

xxv Kerusi P. 176 Kimanis yang ditandingi oleh Datuk Seri Hanifah Aman, mantan Menteri Luar hanya menang dengan majoriti 156 undi sahaja. 
xxvi Penjelasan lanjut tentang perubahan politik dan keputusan pilihanraya dengan terperinci sila lihat Mohd. Noor Mat Yazid dan Md. Saffie Abd. Rahim. (2019). Berakhirnya Simpanan Tetap Barisan Nasional dan Bermulanya Kuasa Politik Baru di Negeri Sabah. dalam Zulkarnain Abdul Rahman, Rosmadi Fauzi dan Amer Saifude Ghazali (eds.), Pilihan raya Umum ke-14: Isu dan Cabaran Malaysia Baru, Kuala Lumpur; Penerbit Universiti Malaya, 359-376.

\section{Rujukan}

Chin. J. (2018). Sabah and Sarawak in the $14^{\text {th }}$ General Election 2018 (GE14): Local Factors and State Nationalism. Journal of Current Southesat Asian Affairs, 37(3),173-192.

Chin. J. (2012). Forced to the Periphery: Recent Chinese Politics in East Malaysia. Dalam Lee Hock Guan \& Leo Suryadinata. Malaysian Chinese: Recent Development and Prospects. Singapura: Institute of Southeast Asian Studies, 109-124.

Danny Wong Tze Ken. (2011). Pilihan Raya Umum ke-12 di Sabah: Beberapa Pemerhatian. dalam Joseph M. Fernando, Zulkarnain Abdul Rahman dan Suffian Mansor (eds), Pilihan Raya Umum Malaysia ke-12: Isu dan pola Pengundian, Kuala Lumpur: Penerbit Universiti Malaya, hal. 249262.

Joseph M. Fernando, Zulkarnain Abdul Rahman dan Suffian Mansor (eds). (2011). Pilihan Raya Umum Malaysia ke-12: Isu dan pola Pengundian, Kuala Lumpur: Penerbit Universiti Malaya.

Lim Hong Hai. (1997). Sabah and Sarawak in Malaysia: The Real Bargain, or What have They Gotten Themselves Into?. Kajian Malaysia, 25 (1\&2), 15-56.

Lim, Markus. (2013). MCA Sebagai Pelarian Politik. Jurnal Pemikir, 71 (Jan-Mac), 31-47.

Loh Kok Wah, Francis. (1997). Understanding Politics in sabah and Sarawak: An Overview. Kajian Malaysia, 25 (1\&2), 1-14.

Mohd. Noor Mat Yazid. (2019). Faktor Sabah, Sarawak dan Johor dalam Pembentukan Kerajaan Pusat Malaysia: Analisi s Pilihanraya Umum ke-13 dan ke-14. International Journal of Law, Government and Communication, 4(4), 87-96.

Mohd. Noor Mat Yazid dan Md. Saffie Abd. Rahim. (2019). Berakhirnya Simpanan Tetap Barisan Nasional dan Bermulanya Kuasa Politik Baru di Negeri Sabah, dalam Zulkarnain Abdul Rahman, Rosmadi Fauzi dan Amer Saifude Ghazali (eds.), Pilihan raya Umum ke-14: Isu dan Cabaran Malaysia Baru, Kuala Lumpur; Penerbit Universiti Malaya, hal. 359-376.

Mohd. Noor Mat Yazid dan Md. Saffie Abd Rahim. (2018). Pencapaian Barisan Nasional dan DUN Majoriti Pengundi kaum Cina di Negeri Sabah: Satu Analisis Perbandingan PRU-13 dan PRU-14. Jurnal Kinabalu, keluaran Khas 2018.

Mohd. Noor Yazid. (2016). Tiang Seri Perlembagaan dan Kuasa Politik Melayu, Kota Bharu: Pustaka Aman Press Sdn. Bhd.

Mohd. Noor Yazid. (2013). DAP, Pakatan dan Politik Malaysia. Jurnal Pemikir, 71 (Januari-Mac), 49-66.

Mohd. Noor Yazid. (2011). Percaturan Kuasa dan Politik Pilihanraya, Kuala Lumpur: Utusan Publications \& Distributors Sdn. Bhd.

Mohd. Noor Yazid. (2010). Merenung Pilihan Raya ke-13: Melayu Gawat, Barisan Tergugat. Jurnal Pemikir, 60, (April-Jun), 81-104.

Tapsell, R. (2018). The Smartphone as the "Weapon of the Weak": Assessing the Role of Communication Technologies in Malaysia's Regime Change. Journal of Current Southesat Asian Affairs, 37 (3), 9-29.

Wong Tze Ken, Danny. (2011). Pilihan Raya Umum ke-12 di Sabah: Beberapa Pemerhatian. dalam Joseph M. Fernando, Zulkarnain Abdul Rahman dan Suffian Mansor (eds), Pilihan Raya Umum Malaysia ke-12: Isu dan pola Pengundian, Kuala Lumpur: Penerbit Universiti Malaya, hal. 249262.

Zulkarnain Abdul Rahman, Rosmadi Fauzi dan Amer Saifude Ghazali (eds.). (2019). Pilihan raya Umum ke-14: Isu dan Cabaran Malaysia Baru, Kuala Lumpur; Penerbit Universiti Malaya. 